\title{
Case Study of Recruitment and Selection of Employees in the Family Businesses of Tasikmalaya
}

\author{
Dedi Rianto Rahadi \\ President University, Indonesia \\ dedi1968@president.ac.id \\ Pandu Cakranegara \\ President University, Indonesia \\ pandu.cakranegara@president.ac.id \\ Genoveva Claudia \\ President University, Indonesia \\ genoveva@president.ac.id
}

\begin{abstract}
Human resource planning within a company includes policies such as recruitment and selection, compensation, performance appraisal, career development, and training and development. Recruitment and selection process becomes the main factor to do professional human resources. The purpose of this research is to know how the concept of recruitment and selection model on family business in small and medium enterprise sector. The object of research is small and medium business in Tasikmalaya city in handicraft sector. The research method used qualitative and data collection through triangulation method where researchers examine the interrelated phenomena from different perspectives. The results showed that family emotional relationship factors often affect the recruitment and selection process of employees. Moreover, Incompetent recruitment and selection models will threaten the performance and even the existence of the company. The poor management of human resources in the family company will have negative impacts such as the outbreak of conflict, the unfavourable working situation, the development of various intrigues, and the high level of employee turnover will ultimately impact on the performance of the company.
\end{abstract}

Keywords: Recruitment and Selection Model, Small and Medium Enterprise Sector

\section{Background}

The true family company is a meeting between two social institutions, namely business and family institutions which have contradictory values and goals. Relationships in business are rational, while the family is emotional. Family membership is based on heredity and lasts almost indefinitely. According to (Huang, Ding, and Kao, 2009), a family firm is defined as an organization owned and/or controlled by members of a family or kinship group. The family business is a business governed and/or managed with the intention to shape and pursue the vision of the business held by a dominant coalition controlled by members of the same family or a small number of families in a manner that is potentially sustainable across generations of the family or families as defined by (Zapalska, et al., 2003). 
The classification of industries among Indonesian family businesses are divided into wholesalers and retailers (36\%); manufacture and distribution (24\%); professional service (14\%); two different industries (13\%); agriculture and fishery (4\%); construction (3\%); finance, real estate, and transportation (2\%); and hotels and entertainment with service (1\%) (Winoto \& Graito, 2008). Values in family businesses tend to be adopted from values in family. Therefore, the core values of family businesses are similar to the ideal values of family. It is stated that family businesses within the hospitality sectors react to a unique set of opportunities and challenges (Andersson et al, 2002).

On the other hand, membership in business is based on competence and only lasts for a certain period of time. Susanto et al. (2007) classified a family business as a company whose shares are at least $25 \%$ owned by a particular family or if less than $25 \%$ of family members have positions on the board of directors or board of commissioners.

The main function of the family is to meet the needs and to cultivate a sense of caring and affection for its members. While the main function of the business is to produce products and financial benefits through structures, systems, and processes are planned and organized. The contradiction of the values and goals of family and business often affects the effectiveness of human resource management within the family enterprise. As it is known, HR planning within a company includes policies such as recruitment and selection, compensation, performance appraisal, career development, and training and development. However, in family companies, family emotional relationships often have an effect on those policies. As a result, the practice of nepotism thrives.

In terms of recruitment and selection, family members are likely to feel entitled to be part of the company. By reason of the difficulty in getting a job, they ask for a job within the company without considering the competencies they have on the grounds of family principles that require family members to help each other unconditionally. On the other hand, for the sake of the company's progress, it is clear that qualified individuals often have to be recruited from outside the family company. The recruitment of too many incompetent individuals will undoubtedly threaten the performance and even the existence of the company.

Recruitment is a decision of human resource management planning regarding the number of employees needed, when needed, and what criteria are needed in an organization (Malthis, 2012). According to Sudarmanto (2009) selection is a process to get the human resources to fill certain positions. Commonly, the terms recruitment and selection are interchangeable but in fact, between recruitment and selection there are differences. Recruitment is a broader terminology of the parable as an attempt to obtain human resources.

In an organization, selection refers to decision method chosen or made within the framework of recruitment. In regards to human resources in small and medium enterprises, one of the fundamental things that become the problem is how to get employees that fit the desired criteria. Many small and medium-sized businesses in recruiting employees are looking for workers who are related to kinship or friendship since they already know the recruited person.

Small and medium business' employees in Tasikmalaya city, especially in handicraft business, are mainly dominated by society around the place of 
business. The number of employees is generally between 5 and 20 depending on the size of the business unit. The ownership of the craft business is inherited from the previous generation. Thus, the process of recruitment and selection of employees is very simple and does not require formal requirements as well as established companies. The formulation of the problem in the research is to know how to model the concept of recruitment and selection on family business. Recruitment and selection process becomes the main factor to do professional human resources. Furthermore, the purpose of this research is to know the concept of recruitment and selection model on family business in small and medium enterprise sector. The object of the research is small and medium business in Tasikmalaya city in handicraft sector.

\section{Literature Review}

\subsection{Family Business}

A family business is an organization with major functions to operate decisions and plan for leadership (Handler, 1989). It is stated that, a family controlled company can comprise a large complex dynastic public company, but equally able to be sole proprietorship, partnership, incorporated entity or any other form of business association where the focus of ownership and / or management control is in the hands of a specific family or collection of families (Balshaw, 2004). Stuart Rock (1991) defined family business as a firm where the family holds a majority of voting shares; where a proportion of the senior management post are held by members of one family and where their children are expected to follow suit.

\subsection{Family business type}

According to Susanto et al. (2007) there are two family business which are:

\section{Family Owned Enterprises (FOE)}

A family owned company managed by professional executives who come from outside the family circle. In this case, the family acts as the owner and does not involve themselves in operations in the field for the management of the company to run professionally. By dividing this role, family members can optimize themselves in the supervisory function.

\section{Family Business Enterprises (FBE)}

A company owned and managed by the family of its founders. So both the management and ownership is held by the same person which are the family. Companies of this type are characterized by the important position in the company held by family members.

\subsection{Paradigm in Family Business}

There are five new paradigms in the family's internal business environment according to Susanto et al. (2007):

a. Employees are a new generation, different from the founders of the company. Keep in mind by family business managers, employees with a high level of education (top-level employees) expect transparency. 
Whereas lower-level employees have the courage to make paradigm demands.

b. Increased issues related to labour, strikes, and so on.

c. The level of family professionalism has begun to increase.

d. The demand for fair and equitable compensation either through a compensation system associated with competition, performance, or contribution.

e. More transparent organizational systems.

\subsection{Advantages and Disadvantages of Family Business}

The advantages and disadvantages of a family business analysed by Marpa (2012) have been reproduce below in Table 1 .

Table 1. Advantages and Disadvantages of Family Business

\begin{tabular}{|c|c|c|}
\hline Indicators & Advantages & Disadvantages \\
\hline $\begin{array}{l}\text { Ownership } \\
\text { Identity }\end{array}$ & $\begin{array}{l}\text { Vision, Commitment, } \\
\text { Values } \\
\text { (Family Company has } \\
\text { vision, commitment and } \\
\text { strong values of the } \\
\text { founder and owner or } \\
\text { successor, because it was } \\
\text { built not for the benefit of } \\
\text { business alone) }\end{array}$ & $\begin{array}{l}\text { Insularity, Over- } \\
\text { attachment, Complacency } \\
\text { (Family firms tend to be } \\
\text { narrow in perspective and } \\
\text { quickly satisfied at certain } \\
\text { achievements) }\end{array}$ \\
\hline $\begin{array}{l}\text { Intergenerational } \\
\text { Transmission }\end{array}$ & $\begin{array}{l}\text { Long term view, } \\
\text { Continuity, Altruism } \\
\text { (Have a long-term view, } \\
\text { are very concerned about } \\
\text { continuous sustainability } \\
\text { and thinking about the } \\
\text { other side) }\end{array}$ & $\begin{array}{l}\text { Conservatism, } \\
\text { Discontinuity, } \\
\text { Decision } \\
\text { (In careful management it } \\
\text { is easy to fall into rigidity, } \\
\text { make bad decisions, even } \\
\text { end a business or sell the } \\
\text { company on the other side) }\end{array}$ \\
\hline $\begin{array}{l}\text { Kin/ Non-Kin } \\
\text { Management }\end{array}$ & $\begin{array}{l}\text { Loyalty, Team Work } \\
\text { Flexibility } \\
\text { (Family members tend to } \\
\text { be more loyal, have strong } \\
\text { foundations to work in } \\
\text { teams and more easily } \\
\text { adapt in any situation) }\end{array}$ & $\begin{array}{l}\text { Conflict, Free-Riding, } \\
\text { Inequities } \\
\text { (Prone to conflict, tend to } \\
\text { be difficult to control and } \\
\text { biased) }\end{array}$ \\
\hline $\begin{array}{l}\text { Wildcard } \\
\text { Succession }\end{array}$ & $\begin{array}{l}\text { Diversity, Renewal, } \\
\text { Pragmatism } \\
\text { (Family companies are able } \\
\text { to thrive in diversity, } \\
\text { pragmatic on the }\end{array}$ & $\begin{array}{l}\text { Instability, Deviance, } \\
\text { Incompetence } \\
\text { (Family firms can fall into } \\
\text { extreme due to incomplete } \\
\text { conflict in succession) }\end{array}$ \\
\hline
\end{tabular}




\begin{tabular}{|l|l|l|}
\hline & $\begin{array}{l}\text { development of the times } \\
\text { and inherit the things that } \\
\text { tend to new things) }\end{array}$ & \\
\hline
\end{tabular}

Source: Marpa (2012: 26-27)

As can be seen in Table 1, the family businesses have more advantage in terms of long term loyalty, concerns and commitment compared to the disadvantages which loss of professionalism.

\subsection{Definition of Recruitment and Selection}

Recruitment is a way of making human resource management planning decisions about the number of employees needed, when needed, and what criteria are needed in an organization. Recruitment is basically an effort to fill the job or vacant in an organization or company with two sources of labour which are the source of the organization and sources from within the organization. Recruitment is defined as a process to get employee candidates who have the ability in accordance with the qualifications and needs of an organization or company (Mardianto, 2014). Recruitment is the process to obtain a number of qualified human resources (employee) to occupy a position or work within a company (Rivai, 2004). Recruitment is an important problem in the procurement of labour (Hasibuan, 2010). If successful withdrawal means that many applicants who enter the application, the opportunity to get a good employee wide open because the company can choose the best among the good.

Selection is an activity in human resource management conducted after the recruitment process is completed (Rivai, 2011). This means that a number of eligible applicants have been selected to be employee within a company. Selection is the process of choosing from a group of applicants who mostly meet the selection criteria for positions available within a company (Simamora, 2004). Furthermore, selection is a process consisting of several specific steps of some groups of applicants who are most suitable and qualify for a particular position (Teguh, 2009).

\section{Research Methodology}

The problem approach used in this research is qualitative approach. A qualitative approach is a method of research focuses on the general principles that are fundamental to the manifestation of the set of symptoms present in human social life.

Data collection techniques that will be used is triangulation method. Denzin and Lincoln (2009) suggest that triangulation to be interpreted as a combination of data sources, researchers, theories, and methodologies in a study of a social phenomenon. This triangulation method aims to obtain accurate data by combining observations, clouds, and document analysis. The data obtained can be primary data and secondary data. Triangulation is a technique of checking the validity of data that utilizes something else outside the data for checking or comparative purposes of that data as defined by Lexy J. Moleong (2009). The object of the research is the SME sector engaged in handicraft business in Tasikmalaya City. 


\section{Results and Discussion}

\subsection{Research Object Profile}

Tasikmalaya is a region appointed by West Java Government as a craft producing center in West Java. Small and medium business sector in Tasikmalaya produces several handicrafts such as Bamboo Handicraft, Geulis Umbrella, Embroidery, Batik, Mendong Plait, Kelom Geulis, and Wooden Handicraft. Table 2 showed the name of the craft product, the number of business units and the number of labour, and the producing areas of handicrafts. Table 2 also showed that most handicrafts are embroidered and supported by a considerable amount of workforce.

Table 2. Product List Micro, Small, Medium Enterprisesin Tasikmalaya City

\begin{tabular}{|l|l|l|l|l|}
\hline No & Product Name & $\begin{array}{l}\text { Number of } \\
\text { units }\end{array}$ & $\begin{array}{l}\text { Puman } \\
\text { Resources }\end{array}$ & $\begin{array}{l}\text { Center(Districts) } \\
\text { Indihiang, Bungursari }\end{array}$ \\
\hline 1 & AnyamanBambu & 75 unit & 632 people & Indihiang, Cihideung \\
\hline 2 & PayungGeulis & 4 unit & 37 people & $\begin{array}{l}\text { Kawalu, Cipedes, } \\
\text { Cihideung, Tamansari, } \\
\text { Cibeureum, } \\
\text { Mangkubumi, Tawang }\end{array}$ \\
\hline 4 & Sulaman/bordirmukena & 1199 unit & 11.674 people & Cipedes, Indihiang \\
\hline 5 & AnyamanMendong & 30 unit & 446 people & Cipedes, Indihiang \\
\hline 6 & KelomGeulis & 454 unit & 5.160 people & $\begin{array}{l}\text { Mangkubumi, } \\
\text { Tamansari, Cihideung, } \\
\text { Tawang }\end{array}$ \\
\hline 7 & ProdukKayu & 240 unit & 1.626 people & $\begin{array}{l}\text { Cipedes, Tawang, } \\
\text { Tamansari, Cibeureum }\end{array}$ \\
\hline
\end{tabular}

Source : Dinas Koperasi \& UMKM Perindag Kota Tasikmalaya, 2016

Some examples of handicraft products produced by craftsmen in Tasikmalaya city, such as beautiful umbrellas, sandals and embroidery are shown below.

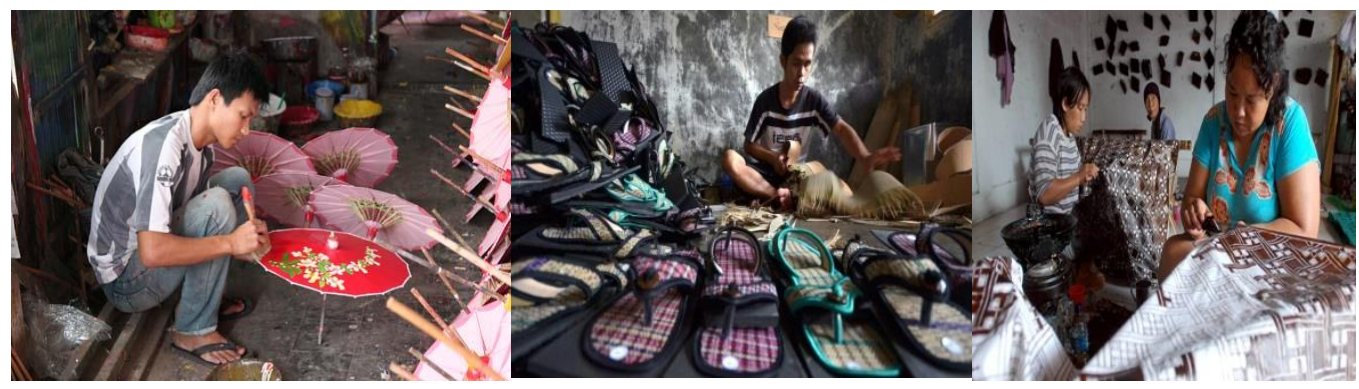

Figure 1. Example of Handicraft Product 
There were 24 small and medium enterprises selected for this study. From the perspective of succession, 5 enterprises were managed by the first generation, and 15 by the second generation and remaining 4 by the third generation. In terms of age of enterprise, 4 were less than 5 years old. Then there were 8 enterprises that were more than 10 years old. The remaining 12 enterprises were 5-10 years old. In terms of ownership, 18 enterprises were fully owned by the family members whereas remaining 6 had shareholders that were not family members. From the point of view of employee composition only 4 enterprises employed mostly nonfamily members, and 8 enterprises employed only family members and the remaining 12 employed mostly family members but had non-members also as employees.

\subsection{Recruitment and Selection Process of Small and Medium Business Sector}

\subsubsection{Recruitmentof Small and Medium Business Sector}

The results of interviews conducted with small and medium-sized businesses related to the recruitment process showed as follows:

First, the small and medium enterprises analyze the needs of employees, such as administrative personnel, shopkeepers and craftsmen. However, it's only applicable when there are a lot of orders. Second, the small and medium enterprises inform by word of mouth to an existing employee and the family that they need employees. Applicant candidates may come from family or outside the family. Some recruited candidates do not apply formally by making an application, rather being interviewed only about their experience. The last, employee recruitment and the time required to do recruitment is not long just more or less two days. The complete recruitment process can be seen in Figure 6.

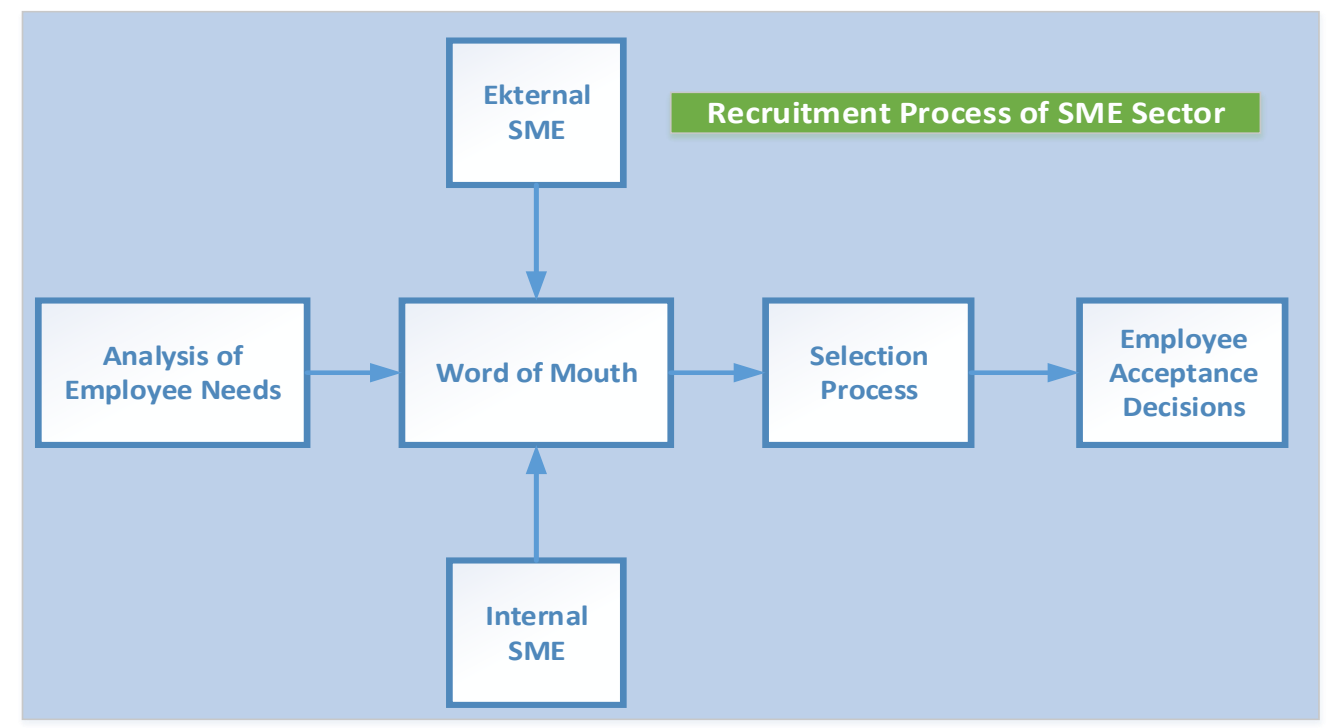

Figure 6. Recruitment Process of Small and Medium Enterprises 


\subsubsection{Small and Medium Business Sector selection}

Based on the preliminary survey conducted through interviews with small and medium business owners, there are some interesting things related to the condition of human resource management in the small and medium enterprise sector. Having told by their owners that they have difficulty in getting employees, especially the one who are capable of carving for example for handicrafts kelomgeulis, umbrella geulis, embroidery and wood products. In addition, some employees who, after several months of work, was not able to carry out their duties properly, but during the selection process when being asked about ability in making products, the employee stated they have good ability in doing the job. Some of these employees come from families and outside the family. Furthermore, according to the owners of small and medium business there was also an employee who was dismissed because they are unable to improve their performance after being given a deadline to do improvement. The selection process is very simple, including interviews related to the expertise they have and their background and experience. However, applicants from the family environment more often than not work directly without interviews. After an interview, applicants usually work immediately. In general, it can be seen in figure 7.

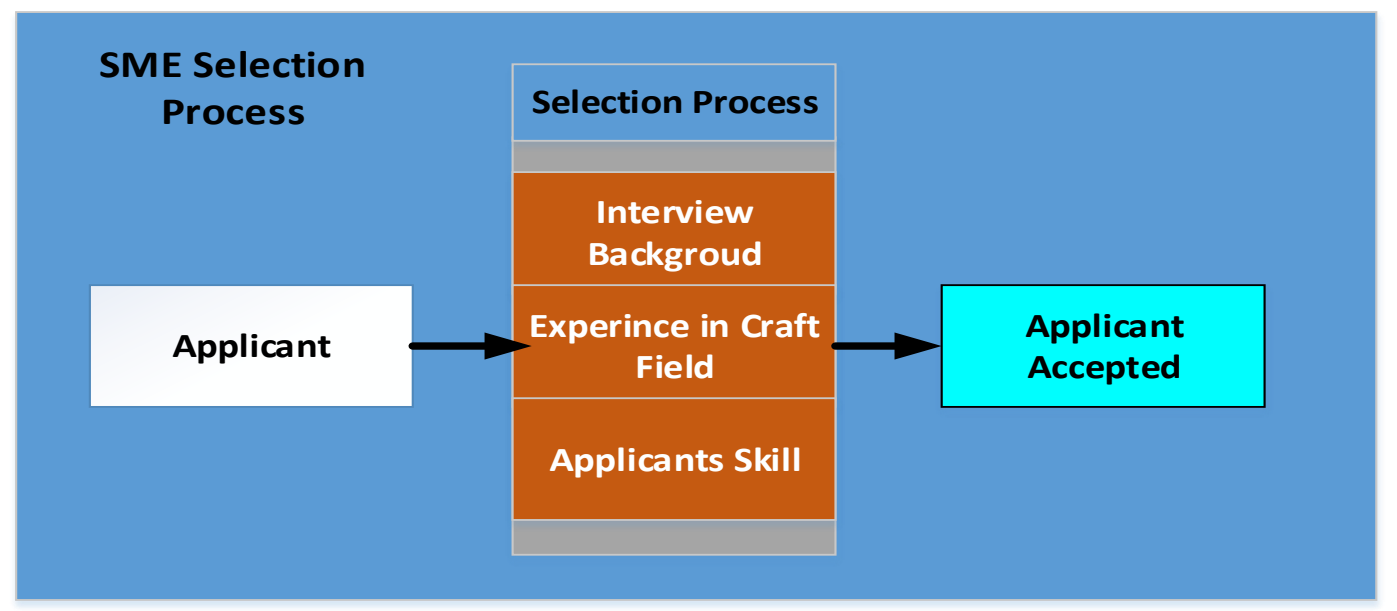

Figure 7.The Selection Process of Small and Medium Enterprises

\subsection{Discussion}

\subsubsection{Recruitment and Selection Process of Small and Medium Business Sector}

In doing recruitment and selection planning, small and medium business sectors should perform in accordance with the procedures and needs, regardless of who the applicant is. The scope and quantity of business that is still relatively small raises several obstacles on the process of recruitment and selection. Among them is the recruitment of prospective applicants and the selection of how the demand for the product increases, otherwise the number of employees will be reduced when demand is small. It needs some cultural approaches to support recruitment 
planning and selection which are good and correct. Among the cultures that can be used as follows:

a. Culture Participation,

In the culture of participation, a more egalitarian and group-oriented relationship developed. Families try to give employees the opportunity to develop their potential. In a culture of participation, families consider employee suggestions and opinions before making a decision. Through participation in decision making, employees will better understand the values of the company and more committed to the decisions taken. Participatory cultural weakness lies in the decision-making process that often takes longer. Thus, the challenge faced is determining which decisions to take quickly and which ones can go through a longer discussion process.

b. Professional Culture

Professional culture is commonly found in family firms that submit business management to professional management. Whereas, Employees focus on individual achievement and career advancement. Professional managers are often neutral and objective towards employees. These professionals rely on the education and training they receive to make rational decisions. Professionals are proactive to improve company performance. The advantage of this professional culture is the inclusion of new management ideas and techniques brought about by professional managers. The disadvantage is the isolation of employees who have long worked in the family company, high absenteeism and entry level, and unhealthy competition.

Whatever culture develops in a successful family company, family members play their part well and feel meaningful about it. In the company there are also an internalization of Family Governance, a living entrepreneurial spirit balanced by risk management, and oriented to superior operations.

\subsubsection{Management of Employees in Small and Medium Enterprise Sector}

There are several things that must be considered by SME managers for the employees to carry out their work well in accordance with the purpose of SMEs regardless of the background of employees, whether coming from family or outside the family.

\section{Compensation}

Compensation given to family members is often based on principles and criteria that confuse family and business affairs. Compensation for family members should also be based more on business values than on family values. To emphasize, there is no single compensation formula for any family company. Each company must design its own compensation system to help achieve the goals of the company and family in the broadest sense. Conditions will get worse when the compensation given is not balanced with the contribution demanded. There will be a sense of 
injustice, which in turn will destroy one of the pillars of corporate culture, namely the need for trust. Low trust will affect the company climate, affect job satisfaction, motivation, and performance.

\section{Performance Appraisal}

In assessing performance, family members working in a company should be evaluated based on professionalism, as well as non-family employees. In order To address potential conflicts resulting from a conflict between family values and business values, an assessment of the performance of family members should include the opinions of subordinates, co-workers and superiors. Non-family professionals should also be given full opportunity and freedom in assessing the performance of family members. This is to avoid bias due to an assessment that is only done by the owner or leader of the family company. The founder's difficulty in making such judgments is aggravated by information problems. Problems arise when non-family employees cover up the incompetence of family members, for example in to secure their position or occupation. While performance appraisals in business institutions are determined by the extent to which an employee's contribution to the company's progress. If a leader or founder of a family company should assess the performance of the family members, the results of the assessment may be biased.

3. Training and Development

The family leader also often finds difficulty in determining training and development for family members in terms of separating individual interests and business interests. From a family perspective, training on family members should focus on what is best for members of the family individually, regardless of company needs. While from a company point of view, training should emphasize learning experiences that will enhance an individual's ability to achieve organizational goals. Commonly the training and development needs of individual family members are not aligned with training needs and organizational development. As a result, resources are wasted, while company performance has not changed significantly.

The poor management of human resources in the family enterprise certainly has a negative impacts such as the outbreak of conflict, the unfavorable working situation, the development of various intrigues, and the high rate of employee turnover. All of them will lead to poor performance of the company. There are a number of things that can be done to overcome the problems above. In the case of selection of family members who will work in the company, the family leader's company should only accept them based on business principles alone. Only family members who have relevant competencies will be accepted to work within the company.

It is important to plan for the career development of family members within the company. Career paths for family members should be tailored to the company's overall objectives, both in the short and long term. Any family member working in a company whose interests and needs are not in accordance with the company's objectives should reconsider their employment status in the company. However, they can be given the opportunity to gain ownership status, claiming part of the 
family's assets to invest in pursuing their professional goals outside the company. The amount of ownership of this family asset is determined on the basis of family values.

\section{Conclusions and Recommendations}

\subsection{Conclusions}

Based on the description above, a conclusion can be drawn that recruitment and selection process in the small and medium business sector is still very simple. The recruitment and selection process prioritizes proximity to small and medium business owners and is not permanent, so the recruitment and selection process can be done at any time. The recruitment and selection process of the family environment is only helpful to the owner and does not have binding regulations.

\subsection{Recommendations}

a) The recruitment and selection process should be conducted according the needs and should not be forced whenever the company does not require new employees.

b) Family business planning therecruitment and selection need to be accordance to business process.

c) The rights and obligations of permanent employees need to be considered in accordance with the ability of small and medium enterprises.

d) The presence of prospective employees from the family environment is still needed to connect and strengthen the relationship of friendship and to help control employees outside the family environment.

\section{References}

Balshaw, T. (2004). Governance in Family Business. Johanesburg: Grant Thornton.

Bork, D. (1986). Family Business Risky Business: how to make it work. New York: Amacom.

Denzin, \& Lincoln. (2009). Handbook of Qualitative Research. Yogyakarta: Pustaka Pelajar.

Handler, W. (1989). Methodological Issues and consideration in studying family business. Family Business Review, II (3), 257.

Hasibuan. (2010). Manajemen Sumber Daya Manusia. Jakarta: Bumi Aksara.

Huang, Ding, \& Kao. (2009). Salient Stakeholder Voice: Family Business and Green Innovation Adoption. Journal of Management and Organization, 15(3), 309-326.

Iansber, \& Ivan. (1999). Succeeding Generations. Boston: Harvard Business School Press.

Mardianto. (2014). Management Recruitmen. Jakarta: Pinasthika Publisher. 
Marpa, N. (2012). Perusahaan Keluarga Sukses atau Mati. Tangerang: Cergas Media.

Moleong, L. J. (2009). Metodologi Penelitian Kualitatif. Bandung: Remaja Rosdakarya.

Rivai, V. (2004). Manajemen Sumber Daya Manusia Untuk Perusahaan Dari Teori ke Praktek. Jakarta: Grafindo Persada.

Rock, S. (1991). Family Firms. England: Director Book-Simon Schuster.

Susanto, A. B., Susanto, P., Wijanarko, H., \& Mertosono, S. (2007). The Jakarta consulting group on family business. Jakarta: The Jakarta Consulting Group.

Simamora. (2004). Riset Pemasaran. Jakarta: Gramedia Utama.

Teguh, A. (2009). Manajemen Sumber Daya Manusia. Jakarta: Graha Ilmu.

Winoto, P., \& Gratio, I. (2008). Analisis interaksi motivasi kerja karyawan perusahaan keluarga $\mathrm{x}$ dan kepemimpinan generasi penerus yang dipersepsikan karyawan. Jurnal Psikologi Sosial, 14(1), 65-79.

Zapalska, e. a. (2003). Environment and Performance of Family Businesses in the Reforming Polish Economy. Journal of East-West Business, 9(1). 